\title{
Mitochondrial disorder caused Charles Darwin's cyclic vomiting syndrome
}

\author{
This article was published in the following Dove Press journal: \\ International Journal of General Medicine \\ 8 January 2014 \\ Number of times this article has been viewed
}

\author{
Josef Finsterer ${ }^{1}$ \\ John Hayman² \\ 'Krankenanstalt Rudolfstiftng, Vienna, \\ Austria; ${ }^{2}$ Department of Pathology, \\ University of Melbourne, Victoria, \\ Australia
}

Background: Charles Darwin (CD), "father of modern biology," suffered from multisystem illness from early adulthood. The most disabling manifestation was cyclic vomiting syndrome (CVS). This study aims at finding the possible cause of CVS in CD.

Methods: A literature search using the PubMed database was carried out, and CD's complaints, as reported in his personal writings and those of his relatives, friends, colleagues, biographers, were compared with various manifestations of mitochondrial disorders (MIDs), known to cause CVS, described in the literature.

Results: Organ tissues involved in CD's disease were brain, nerves, muscles, vestibular apparatus, heart, gut, and skin. Cerebral manifestations included episodic headache, visual disturbance, episodic memory loss, periodic paralysis, hysterical crying, panic attacks, and episodes of depression. Manifestations of polyneuropathy included numbness, paresthesias, increased sweating, temperature sensitivity, and arterial hypotension. Muscular manifestations included periods of exhaustion, easy fatigability, myalgia, and muscle twitching. Cardiac manifestations included episodes of palpitations and chest pain. Gastrointestinal manifestations were CVS, dental problems, abnormal seasickness, eructation, belching, and flatulence. Dermatological manifestations included painful lips, dermatitis, eczema, and facial edema. Treatments with beneficial effects to his complaints were rest, relaxation, heat, and hydrotherapy.

Conclusion: CVS in CD was most likely due to a multisystem, nonsyndromic MID. This diagnosis is based upon the multisystem nature of his disease, the fact that CVS is most frequently the manifestation of a MID, the family history, the variable phenotypic expression between affected family members, the fact that symptoms were triggered by stress, and that only few symptoms could not be explained by a MID.

Keywords: hyperemesis, cyclic vomiting, fatigue, metabolic disease, mitochondrial disorder, multisystem disorder, respiratory chain

\section{Introduction}

Cyclic vomiting syndrome (CVS) is a rare, chronic, debilitating, functional, gastrointestinal disorder initially described in children ${ }^{1}$ but increasingly recognized in adults. ${ }^{2,3}$ CVS is characterized by recurrent, stereotypic episodes of intense nausea, intractable nonbilious vomiting, and abdominal pain lasting hours or days. ${ }^{4,5}$ Between the attacks, patients remain symptom-free and return to baseline health, unless CVS has become coalescent. ${ }^{5}$ The most common prodromal symptoms are nausea and abdominal discomfort. ${ }^{6}$ In adults, CVS is commonly associated with anxiety and depression. ${ }^{7}$ Triggering factors include stroke, ${ }^{6}$ intake of morning medication, ${ }^{6}$ or cannabis abuse. ${ }^{8}$ Severity of CVS in adults ranges from mild disease with infrequent episodes to severe, life-disabling disease requiring multiple emergency department visits or
KAR, PO Box 20, II 80 Vienna, Austria

Tel +43 । $7 \mid 16592085$

$\mathrm{Fax}+43$ | 478| 7| |

Email fifigs I@yahoo.de (c) (i) (c) 2014 Finsterer and Hayman. This work is published by Dove Medical Press Limited, and licensed under Creative Commons Attribution - Non Commercial (unported, v3.0) License. The full terms of the License are available at http://creativecommons.org/licenses/by-nc/3.0/. Non-commercial uses of the work are permitted 列 Limited. Information on how to request permission may be found at: http://www.dovepress.com/permissions.php 
frequent hospitalizations. ${ }^{9,10}$ Frequently, CVS is associated with migraine, particularly in children, ${ }^{11}$ or mitochondrial dysfunction. ${ }^{12}$ Onset of CVS is earlier among those who develop migraine. ${ }^{11}$ In adults, CVS is frequently associated with autonomic dysfunction, more frequently with sympathetic than with parasympathetic dysfunction. ${ }^{13}$ Females with CVS frequently have hyperemesis during pregnancy.

CVS occurs in all age groups, with a mean age of onset of 4 years in children ${ }^{14}$ and 35 years in adults. ${ }^{5}$ The demographic profile and disease characteristics are similar in pediatric and adult-onset CVS; however, pediatric CVS more likely occurs in females and has a higher prevalence of concomitant neurological abnormalities. ${ }^{3}$ In a study of 101 CVS patients, $65 \%$ were female and $29 \%$ were pediatric cases. ${ }^{3}$ The prevalence of cognitive impairment is higher in children as compared to adults. ${ }^{3}$ Latency between onset and diagnosis is longer in pediatric as compared to adult patients. ${ }^{3} \mathrm{CVS}$ is a rare condition in adults but is regarded as the second most common cause of recurrent vomiting after gastroesophageal reflux in children, affecting $1.9 \%$ of school-aged children. ${ }^{15} \mathrm{CVS}$ is present in about $2 \%$ of Scottish and Western Australian school children. ${ }^{16,17}$ Despite increasing awareness, CVS often remains unrecognized for months or even years in children and adults.

The etiology is multifactorial and heterogeneous since CVS has been described in patients with mitochondrial disorders (MIDs) and fatty acid oxidation disorders (FAODs).,18 In pediatric cases with migraine, CVS was associated with the mitochondrial DNA single nucleotide polymorphisms m.16519C $>$ T and $\mathrm{m} .3010 \mathrm{G}>\mathrm{A} .{ }^{19-22} \mathrm{CVS}$ was reported in a patient with Kearns-Sayre syndrome ${ }^{23}$ due to a $3 \mathrm{~kb}$ mitochondrial DNA deletion with a heteroplasmy rate of $30 \%-40 \%$ in blood, and it was also a phenotypic feature in seven of eleven patients with mitochondrial encephalomyopathy, lactic acidosis, and stroke-like episodes (MELAS) first described in the literature. ${ }^{24}$ Episodic vomiting is also a frequent feature of other MELAS patients, ${ }^{12}$ mitochondrial neurogastrointestinal encephalomyopathy, ${ }^{25}$ mitochondrial depletion syndrome due to MPV17 or TYMP mutations, ${ }^{26}$ Leigh-syndrome, ${ }^{27}$ or nonsyndromic MIDs. ${ }^{28}$ Additionally, maternal inheritance of symptoms and signs and abnormal urinary excretion of organic acid in children suggested MID to have been causative. ${ }^{29-32}$ Some CVS patients may also present with lactic acidosis. ${ }^{10,33} \mathrm{CVS}$ has been regarded a manifestation of migraine by some authors ${ }^{34}$ since it evolves to migraine in one third of the cases. ${ }^{32,35}$ Further arguments for a mitochondrial defect as cause of CVS are the frequent transmission of CVS via a maternal trait of inheritance, ${ }^{32}$ the frequent association of CVS with other typical clinical manifestations of a MID, ${ }^{11,36,37}$ the abnormal urinary organic acid profile in some CVS patients, ${ }^{32}$ and the beneficial response of CVS to compounds such as L-carnitine or coenzyme-Q, which are frequently used as supportive measures in MIDs. ${ }^{12}$ In a 20-year-old adult, CVS was attributed to the FAOD multiple acyl-coenzyme A dehydrogenase deficiency, manifesting with anion gap metabolic acidosis, nonketotic hypoglycemia, collapse, multiorgan failure, and death. ${ }^{18}$

Generally, CVS is diagnosed upon the history, clinical presentation, and after exclusion of other possible causes. ${ }^{38}$ In adults, CVS is diagnosed according to the Rome III criteria, which include stereotypic, acute-onset episodes of nausea and vomiting lasting $<1$ week, more than two episodes within the previous year, and absence of nausea or vomiting between the episodes. ${ }^{39}$ In children, CVS is diagnosed according to essential criteria (recurrent, severe, discrete episodes of vomiting with varying intervals of normal health between episodes) and supportive criteria (vomiting episodes and patterns which are similar to each other within each individual case). ${ }^{40}$ Laboratory and radiographic studies are typically normal..$^{32,35,40}$ Because of the lack of awareness, CVS is often diagnosed with delay, particularly in adults. ${ }^{5}$ The diagnosis may be also delayed because there is no specific test to confirm the diagnosis. In cases in which CVS remains unrecognized, patients undergo unnecessary diagnostic procedures and treatment without benefit ${ }^{41}$ and may develop interepisodic nausea and loss of periodicity (coalescence of symptoms). ${ }^{3}$ Differential diagnoses include hydrocephalus, brain tumor, Budd-Chiari malformation, ${ }^{6}$ medium chain acyl-CoA dehydrogenase deficiency, lateonset form of glutaric acidemia type II, short chain acyl-CoA dehydrogenase deficiency, short-chain 3-hydroxy acyl-CoA dehydrogenase deficiency, gastrointestinal reflux, and chronic cannabis abuse. ${ }^{4}$ These diagnoses need to be excluded before diagnosing CVS.

There is no standard, evidence-based, generally accepted treatment of CVS. ${ }^{5}$ Only symptomatic measures are available, which can be separated into prophylactic measures and treatment of the acute symptoms. Prophylactic treatment is usually carried out with cyproheptadine (age $\leq 5$ years) or amitriptyline (age $>5$ years). Some patients may benefit from flunarizine, a selective calcium antagonist, ${ }^{34}$ and some patients additionally respond to topiramate, coenzyme-Q, or L-carnitine. ${ }^{3}$ The response rate to amitryptiline was reported as $52.7 \%$ in an open-label, subject recall-based study in children and adults. ${ }^{12}$ The efficacy of coenzyme-Q is similar to 
that of amitryptiline. ${ }^{14}$ Therapy of acute symptoms includes application of intravenous fluids with up to $10 \%$ glucose to limit ketosis. ${ }^{42}$ In addition to fluid resuscitation, various drugs are applied; most frequently antiemetic medication, like ondansetron, antimigrainous drugs, $\alpha$-blocking agents such as dexmedetomidine or clonidine, proton-pump inhibitors, or sedatives are applied. ${ }^{5}$ Sartanes have also been shown to have beneficial effects in episodes of CVS. ${ }^{43}$ In patients with intractable vomiting, valproate or phenobarbital may be helpful as a prophylaxis of vomiting. ${ }^{43}$ Most patients report a benefit from hot bathing, ${ }^{8}$ which is why they spend hours in a bath or under a shower. ${ }^{44}$ In most children, symptoms are relieved by sleep. ${ }^{40}$ Age at onset does not predict the response to standard treatment, ${ }^{3}$ and compliance appears to be the only factor associated with a favorable response. ${ }^{3}$

One of the historic celebrities in whom CVS is suspected is Charles Darwin (CD). ${ }^{45,46}$ According to his own description (letters, autobiography, diary of illness), the description of his wife Emma (diary), historical witnesses (correspondence with friends, colleagues, doctors), and reports of others about his condition, he most likely suffered from CVS for years, but it is unclear if CVS in CD was due to a MID, a FAOD, or another cause. This study aims at finding out which of the possible causes of CVS could have been responsible for CD's symptoms.

\section{Materials and methods}

A literature search using the PubMed database was carried out, and CD's complaints, as reported in his diary, his correspondence with friends, colleagues, his doctors, or in his diary of illness, and in the descriptions by his wife, children, colleagues, the writings of his doctors and biographers were compared with various manifestations of MIDs or FAODs described in the literature.

\section{Results}

\section{Biography of CD}

CD was born on February 2, 1809 as the fifth child to Robert Darwin and Susannah Wedgwood. Susannah had two sisters (Mary Anne, Sarah) and three brothers (Josiah, Richard, Tom) (Figure 1). CD was brought up in Shrewsbury, where he also went to school (Table 1). In October 1825, CD started to study medicine in Edinburgh but gave up his medical studies after 2 years to switch to theology in Cambridge in January 1928 (Table 1). After graduation from Cambridge, he was selected to participate in an expedition aboard the ship "Beagle" to South America and around the world. This expedition lasted 5 years, from December 1831 to October 1836, and provided the basis for his theories on human evolution and sexual selection. After his return, he relocated to London in March 1837. In January 1839 CD married his first cousin Emma, who bore him ten children between 1843 and 1856, seven of which survived into adulthood (Henrietta, George Howard, Elizabeth, Francis, Leonard, Horace, Charles) (Figure 1). In 1842 the Darwins moved to Downe, Kent, south of London. Since his return from the expedition, he had started extensive experimental and publicatory activities. Between 1858 and 1859 he wrote a short version of the "Origin of Species." He also became closely involved in the activities of national scientific societies and held several official positions. Along with his scientific passions, he engaged with many of his national and international colleagues and combatants and gained international reputation and increased attention. However, most of his activities were frequently interrupted by a chronic, episodic, slowly progressive illness that forced him to reduce or stop his work for days or weeks and lastly resulted in social retreat. Despite these restrictions and limitations, he continued his pioneering and inspiring work and correspondence and further developed his revolutionary theories on evolution until his older years. He died in April 1882 at the age of 73 years, most likely from myocardial infarction during an episode of his illness.

\section{Medical history}

Contrary to his celebrity for his scientific merits, CD is hardly known for the disease he suffered from since adolescence throughout the rest of his life. In recent years however, his illness has gained attention, and an increasing amount of literature has been published on this topic. ${ }^{45-50}$ His medical history is noteworthy for dyslexia and amusia, and at school-age in Shrewsbury he developed prominent flatulence, which is why he was given the nickname "gas" (Table 2). ${ }^{51}$ During his time as a student in Edinburgh and Cambridge he developed periodic nausea, retching, and bilious vomiting, occasionally with clots of blood (hematemesis). These symptoms were associated with bloating and abdominal pain. ${ }^{52}$ He vomited 2-3 hours after eating but did not vomit food, which is why he did not lose weight. Initially, he seemed to have been an athletic young male, but at age 20 years, he first reported intense fatigue and lethargy after attending two music concerts within one day. ${ }^{53}$ During the 5-year circumnavigation aboard the "Beagle," he was affected by intense seasickness, which became worse as the voyage progressed. Occasionally, CD was also sick when ashore. During land excursions he sometimes developed tiredness, fatigue, general weakness, lethargy, and exhaustion, giving him the feeling of being 


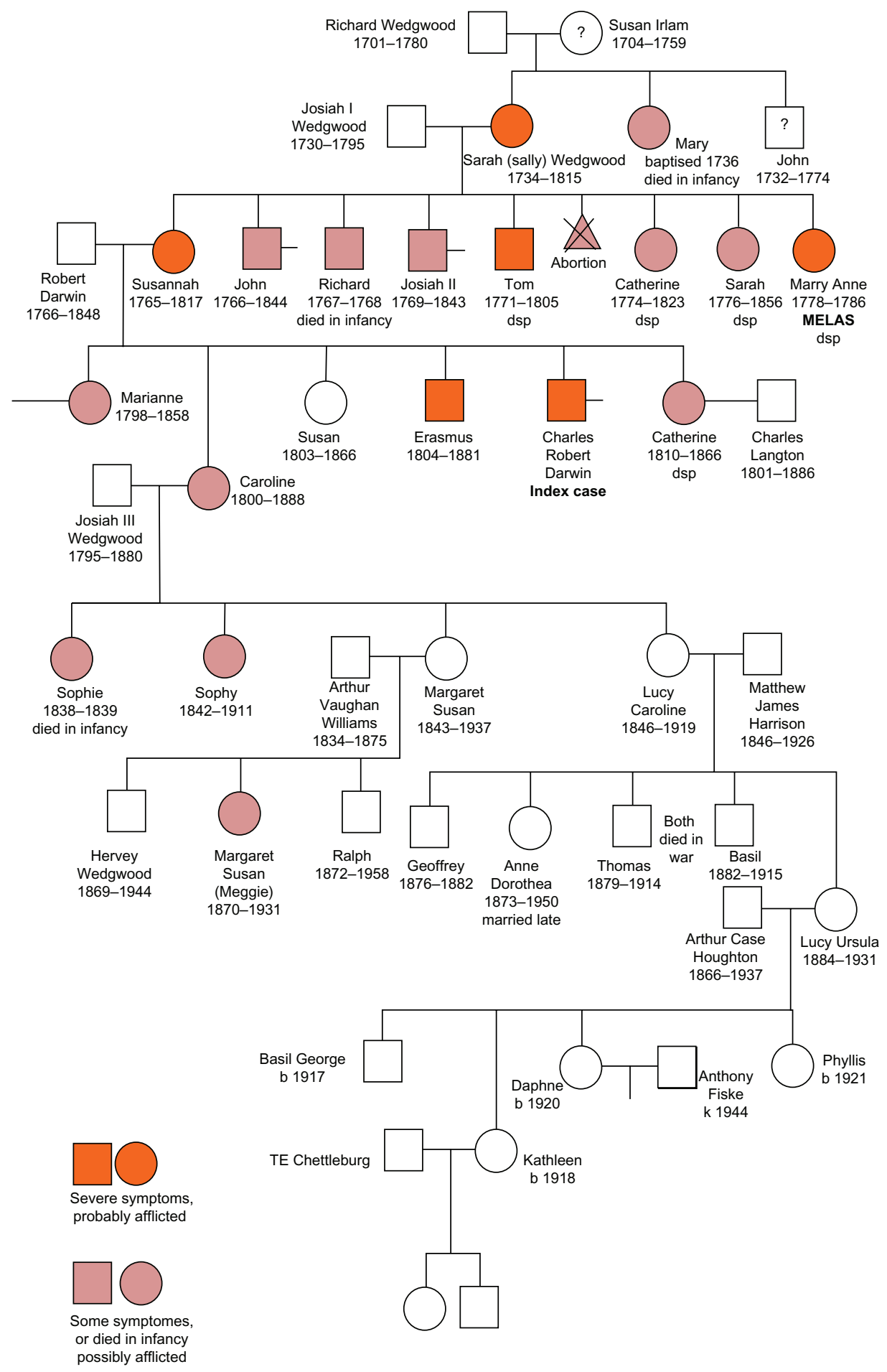

Figure I Family tree of Charles Darwin's (CD) relatives.

Notes: First Generation: Susan Irlam, who died relatively young ( 55 years), had three children. John, who died suddenly at age 42 years; Mary, who died in infancy; and Sarah, the mother of Susannah and grandmother of CD, who developed chronic illness.

Second Generation: John Wedgwood died suddenly, aged 42 years, "stricken with a severe illness." He was seen by Dr Erasmus Darwin but "nothing could be done." A sudden, severe illness, causing death after a week or so would be consistent with acute pancreatitis and peritonitis. Sarah (Sally) Wedgwood, wife of Josiah (Josiah I) Wedgwood, mother of Susannah and grandmother of CD, was healthy and active when young, but she developed chronic illness with severe arthritis and "rheumatism." Some of her symptoms are those of the condition known today as fibromyalgia. In addition to her eight children, all of whom had evidence of hereditary disease, she had serious illness after a miscarriage. This illness was diagnosed by Dr Erasmus Darwin as "inflammation of the liver," most likely an acute fatty liver. Mary Wedgwood died in 1736, the year of her baptism. British Genealogy ${ }^{108}$ states that she had died in the year of her birth. The widowed Richard Wedgwood is reported as having two children only.

Third Generation: Susannah (Sukey, Susan) Darwin, CD's mother, had a history of vomiting and boils as a child and later had "difficulties" with pregnancies, which was probably hyperemesis. Famously "never quite well and never very ill" and "everyone seems young but me." She had a history of motion sickness, and died with sudden, severe abdominal illness and probable acute hemorrhagic peritonitis, an illness similar to that of her maternal uncle John. John suffered from (essential?) tremor all his life.

(Continued) 
Essential tremor may occur in association with dysautonomia; both CD and his maternal uncle, Tom, had evidence of dysautonomia. Richard died in infancy with an "acute abdominal complaint" suggesting acute pancreatitis. Josiah II, developed Parkinson's disease in later life. Tom, suffered headaches and abdominal pains even as a student. He also had periods of lethargy, periodic vomiting, suffered severe seasickness, had heat and cold intolerance, became addicted to opium, and died by opium over-dosage at the age of 34 years. Catherine "Kitty" described as "somewhat masculine" and the least attractive of the adult sisters, developed an abdominal tumor that reached an immense size. Her masculine appearance suggests that she may have had polycystic ovaries or the Stein-Leventhal syndrome, the most common cause of such endocrine effects in females. Patients with this syndrome may develop cystic ovarian tumors that, if untreated, may become very large. Sarah had no history of illness, but in the one portrait of the family she is depicted as having ocular hypertelorism. She never married, but she was apparently attractive and declined several proposals of marriage. Mary Anne was of short stature and had physical and intellectual disabilities. She suffered headaches, fits, periods of paralysis and blindness, and she progressively declined until death at the age of 8 years.

Fourth Generation: Marianne Parker, CD's eldest sister, married Dr Henry Parker in 1824. Even before her marriage she had a reputation for irritability: “... of course you know how peevish Maryane (Marianne) is when she is unwell." The Parkers had five children, four boys and a girl. There is no record of living female line descendants of any of these children. Marianne died in 1858, at the relatively young age of 60 years, 2 years after her husband. "We have just heard of my sisters Marianne Parker's death, - a blessed relief after long continued and latterly very severe suffering." No detailed description of her sufferings has been found but it is possible she experienced symptoms that today would be called fibromyalgia. Caroline Wedgwood married her first cousin, Josiah III. They had four daughters; the first died in infancy. She had a prolonged period of mental illness that lasted for 12 years. Emma, Charles' wife, writing to her daughter Henrietta, described her:

[...] looking so ill and depressed. Her health is so bad and she feels so desponding about her life and feels so utterly unable to reconcile herself to the loss of Margaret (a daughter who married) [...]. She has grown so immensely large and feels so great a figure that she can hardly bear to go anywhere. ${ }^{90}$

Caroline became careless in her appearance and forgetful of even the simplest details of managing a household and a family. She recovered from this period of severe illness but was always described as being "eccentric" and "secretive." In her old age she was severely handicapped with arthritis. Susan Darwin, the surrogate mother of the family after Susannah's death, was the mistress of the household, the keeper of accounts, the schoolmistress who corrected Charles' spelling, and as well, the generous aunt who brought up Marianne's five children after her death in 1858. She never married or had any children of her own and died only a few months after her younger sister Catherine. Although she died at the relatively young age of 63 years, there is no record of her having had illness. Erasmus Alvey Darwin, CD's elder brother was described as having "rheumatism" at an early age and being very pale and was regarded as a chronic invalid throughout his adult life. CD wrote: "All my sisters are well, except Mrs Parker, who is much out of health; and so is Erasmus at his poor average." In later life he had episodic attacks of pain and nausea. CD noted of his brother: "He takes no wine or smoke, but sticks to his opium with many groans." Erasmus died in August I88I at the age of 76 years. Catherine Langton married Charles Langton, a widower, in I863 at the age of 53 years. Like her mother before her and two of her older sisters, Catherine was never "completely well," and at the time of her marriage she was described as being "in poor health" and having a "depressive disposition." When she died, CD wrote to Hooker: "Poor thing she suffers much." She never had children.

Fifth Generation: Initial searches have found little record of Marianne Parker's five children, four boys and one girl, particularly no history of illness. The four boys were pallbearers at their grandfather's (Dr Robert Darwin's) funeral, a funeral that CD was unable to attend due to illness. The one daughter, 17-year-old Mary Susan Parker, was described by CD: "who though dull is a nice girl." She married Major Edward Mostyn-Owen and had two daughters and three sons. Maud Mostyn-Owen died at the age of 18 years, and there is no record of her having children. No record of Henrietta Susan Mostyn-Owen has been found. Sophie Wedgwood died in infancy. Sophy Wedgwood, Caroline's eldest surviving daughter, never married and became a recluse after her mother died. Even before this, Emma, CD's wife, noted: "poor Sophy strikes one anew every time one sees her as utterly dead and quite as much dead to mother and sisters as to outsiders." She is recorded as becoming very miserly, serving guests at a dinner party with a single orange, secreting food in corners throughout her house, and searching rubbish bins for scraps that she considered of value. Margaret Wedgwood, Caroline's second surviving daughter, married Arthur Vaughan Williams. There is no record of Margaret having illness, and she helped her sickly elder sister, Sophy, nurse their dying mother. Their younger son, Ralph Vaughan Williams (1872-1958), became a famous composer, and was assisted in his music work by his older sister Margaret Susan (Meggie). Meggie, although vivacious and talented early in life, developed marked cognitive decline and spent the last decade of her life in a vegetative state. The older son, Hervey Wedgwood, is known to have married but no other details have been found. Lucy, Caroline's third surviving daughter, married Matthew James Harrison, and they had three sons and two daughters. Lucy migrated with her husband to Canada where she died. No record of illness in herself, her children, or her children's children has been found.

Abbreviations: b, born; dsp, decessit sine prole (died without issue); k, killed; MELAS, mitochondrial encephalomyopathy, lactic acidosis, and stroke-like episodes.

"knocked-up" (Table 2). Additionally, attacks of headache and visual disturbance occurred and were of such a severity that they incapacitated him for days (Table 2) ${ }^{51}$ During the years after his return from the expedition, he still suffered from episodic nausea, retching, vomiting, palpitations, episodes of panic, and headache. ${ }^{54}$

His attacks could be triggered by stressful events, excitement, pleasurable events, anxiety, infections, exposure to heat (in South America), or exposure to cold. Even the birth of his first child (Erasmus) in 1839 caused severe headache before the birth and a "knocked-up" state after delivery. Because of early exhaustion, $C D$ increasingly retreated from visiting friends, joining parties, or inviting colleagues during his stay in London. During 1840 CD's illness worsened, and he developed erructation. ${ }^{56}$ At the same time he started to complain about temporary numbness of all his fingers. ${ }^{57}$ After having moved to Downe, south of London in 1842, the Darwins returned into society, but his health almost always suffered from the excitement with attacks of violent shivering and vomiting (Table 2).$^{58}$ For this reason, he gave up all dinner parties and when scheduling a meeting with friends or colleagues, he warned them in advance that he might fail to come because of his uncertain health. ${ }^{59}$ In 1845 he realized that he could no longer attend meetings, ${ }^{60}$ and since 1848 , he reported eye symptoms such as fiery spikes or dark clouds before the eyes. In 1848 he experienced a first episode of depression. His illness further progressed such that he could not even attend his father's funeral in November $1849 .{ }^{61}$ In 1852 he complained that even day trips to London brought on fatigue. Traveling to Sydenham in 1854 to watch the opening of the new Crystal palace by Queen Victoria again resulted in sickness and headache.

Since 1849 he repeatedly underwent hydrotherapy at Dr James Manby Gully's institute at Malvern with a beneficial effect. ${ }^{62-64}$ In 1860 he should have attended a meeting of the British Association for the Advancement of Science in Oxford to defend his theory but could not do so because of another episode of nausea, vomiting, and headache. ${ }^{65}$ In 1861 $\mathrm{CD}$ could not attend the funeral of his mentor John Stevens Henslow, and in 1862 he gave a talk at the Linnean Society 
Table I Benchmark data of Charles Darwin's biography

\begin{tabular}{|c|c|}
\hline Date & Event \\
\hline February 12, 1809 & Birth \\
\hline Boyhood & School in Shrewsbury \\
\hline October 1825 & Start of medical studies in Edinburgh \\
\hline Summer 1826 & Climbs Mt Snowdon without problems \\
\hline January 1828 & Starts theology studies at Cambridge \\
\hline December I831 & Start of the expedition with the "Beagle" \\
\hline January 1832 & Praia, Cape Verde islands \\
\hline February 1832 & Salvador de Bahia, Brasil \\
\hline December 1832 & Fireland \\
\hline April-November 1833 & Excursions to Uruguay and Argentina \\
\hline July 1834 & Valparaiso, Chile \\
\hline September 1835 & Galapagos islands \\
\hline November 1835 & Tahiti \\
\hline January 1836 & Sidney \\
\hline May 1836 & Kapstadt \\
\hline October 1836 & Return from the 5-year expedition \\
\hline March 1837 & Residence in London \\
\hline January 1839 & Marriage to Emma, his first cousin \\
\hline November 1842 & Residence in Downe, London south \\
\hline 1849 & Hydrotherapy in Malvern \\
\hline April 1851 & Death of his favorite daughter Annie \\
\hline November 1859 & Publication of "On the origin of Species....." \\
\hline July 1858 & $\begin{array}{l}\text { Presentation of the theory of evolution at } \\
\text { the Linnean society }\end{array}$ \\
\hline June 1860 & $\begin{array}{l}\text { Session of the "British Assc for the } \\
\text { Advancement of Science" }\end{array}$ \\
\hline January 1868 & $\begin{array}{l}\text { Publication of his book "The Variation of } \\
\text { Animals and Plants under Domestication" }\end{array}$ \\
\hline |87| & $\begin{array}{l}\text { Publication of his book "The Descent of } \\
\text { Man, and Selection in Relation to Sex" }\end{array}$ \\
\hline 1872 & $\begin{array}{l}\text { Publication of his book "On the Expression } \\
\text { of the Emotions in Man and Animals" }\end{array}$ \\
\hline April 19, 1882, 4 pm & Death \\
\hline
\end{tabular}

in London, which triggered another episode of vomiting and headache. During the same year he experienced a relapse of his skin problems (eczema, facial edema). ${ }^{66}$ In summer of $1863 \mathrm{CD}$ lost his memory for the first time, which was interpreted by his family as epileptic seizure. ${ }^{67}$ In 1864 he was incapacitated for months because of nausea and vomiting. ${ }^{68,69} \mathrm{An}$ ice bag therapy (application of ice to the skin) in 1865 was ineffective. ${ }^{70}$ In 1867 he experienced two episodes of short-term paralysis, inability to speak, and memory loss. In 1869 CD's health improved transiently, allowing him to travel and to attend meetings but nausea, flatulence, and colics remained constant. ${ }^{65}$ In 1875 he failed to attend the funeral of his friend Charles Lyell. His last three years of life were dominated by increasing tiredness, chest pain, and an irregular pulse (atrial fibrillation?). ${ }^{71}$ For his shivering and nonresistance to cold, fires in the grates were kept burning all year long in his home. ${ }^{51} \mathrm{CD}$ suffered from caries and tooth decay, possibly due to his high sugar diet (he was fond of
Table 2 Onset of Charles Darwin's clinical manifestations, including those suggestive of mitochondrial disorder

\begin{tabular}{|c|c|c|c|}
\hline Symptom & Onset & $\begin{array}{l}\text { Typical MID } \\
\text { feature }\end{array}$ & Reference \\
\hline \multicolumn{4}{|l|}{ Clear onset } \\
\hline Dyslexia & Boyhood & Yes & 51 \\
\hline Scarlet fever & 9 years & No & 47 \\
\hline Flatulence & Boyhood & Yes & 58,65 \\
\hline Painful lips, eczema & 19 years & No & $65,81,82$ \\
\hline Periodic nausea, vomiting & 20 years & Yes & $55,60,65,69$ \\
\hline Fatigue, lethargy & 20 years & Yes & 43 \\
\hline Abnormal seasickness & 22 years & Yes & 58 \\
\hline Palpitations & 22 years & Yes & $58,83,84$ \\
\hline Faintness, sinking feeling & 23 years & Yes & \\
\hline Exercise intolerance & 23 years & Yes & 58 \\
\hline Headache & 23 years & Yes & $55,85-87$ \\
\hline Panic attacks, fear & 29 years & No & 58 \\
\hline Overtiredness & 30 years & Yes & 88,89 \\
\hline Exhaustion & 30 years & Yes & 90 \\
\hline Eructation, belching & 31 years & Yes & 91 \\
\hline Muscle weakness & 33 years & Yes & 58 \\
\hline Fatigue & 43 years & Yes & $53,55,64$ \\
\hline Prostration & 49 years & Yes & 92 \\
\hline Loss of memory & 54 years & Yes & 67 \\
\hline Myalgia & 55 years & Yes & 93 \\
\hline Atrial fibrillation & 63 years & Yes & 51 \\
\hline \multicolumn{4}{|l|}{ Unclear onset } \\
\hline Finger numbness & Uk & Yes & 57,66 \\
\hline Dental problems & Uk & No & 51 \\
\hline $\begin{array}{l}\text { Tan skin } \\
\text { (hyperpigmentation) }\end{array}$ & Uk & No & 51 \\
\hline Transient weakness & Uk & Yes & 51 \\
\hline Bloating, abdominal pain & Uk & No & 51 \\
\hline $\begin{array}{l}\text { Dizziness, whizzing, } \\
\text { swimming head }\end{array}$ & Uk & Yes & 51 \\
\hline Muscle twitching & Uk & Yes & 51 \\
\hline $\begin{array}{l}\text { Sweating, temperature } \\
\text { sensitivity }\end{array}$ & Uk & Yes & 51 \\
\hline Muscle weakness & Uk & Yes & 51 \\
\hline Visual disturbances & Uk & Yes & 51 \\
\hline $\begin{array}{l}\text { Edema of face, arm, } \\
\text { knee, leg }\end{array}$ & Uk & Yes & 51 \\
\hline Lumbago & Uk & No & 51 \\
\hline Speech arrest & Uk & Yes & 51 \\
\hline Depression & Uk & Yes & 51 \\
\hline Tight chest, dyspnea & Uk & Yes & 51 \\
\hline Recurrent boils & Uk & No & 51 \\
\hline Hematemesis & Uk & No & 51 \\
\hline $\begin{array}{l}\text { Chest pain, death } \\
\text { April 19, } 1882 \text { from } \\
\text { myocardial infarction }\end{array}$ & 73 years & & \\
\hline
\end{tabular}

Abbreviations: MID, mitochondrial disorder; Uk, unknown.

pudding) but possibly also for his cyclic vomiting. He also suffered from recurrent episodes of boils, and skin abscesses due to staphylococcus infection. ${ }^{72} \mathrm{CD}$ 's death was associated with chest pain and dyspnea during one of his episodes, most likely from myocardial infarction or acute heart failure, but 
it cannot be excluded that chest pain was due to esophagitis, gastroesophageal reflux, Barrett's esophagus, or a perforating peptic ulcer. ${ }^{47}$

\section{Family history}

The youngest sister of CD's mother (Mary Anne Wedgwood) was of short stature, displayed physical and mental disabilities, had experienced recurrent seizures followed by partial weakness (Todd's paresis), and episodes of blindness. She died with progressive dementia at the age of 8 years (Figure 1). ${ }^{73}$ The sister of Mary Anne (Sarah) presented with clear hypertelorism as can be determined from available photographs. One brother of the mother (Josiah) developed late-onset parkinsonism, and one brother (Richard) died suddenly in infancy (Figure 1). Another of CD's uncles (Tom Wedgwood) had headaches as a student and later developed severe abdominal pain, such that he "rolled around the floor in agony." ${ }^{47}$ Like CD, he suffered from abnormal seasickness. ${ }^{73} \mathrm{He}$ died from an opium overdose at the age of 34 years. CD's mother was "never quite well."73 As a child she suffered from vomiting and boils. She had difficulties with her pregnancies, spending much time in bed, which was most likely a result of hyperemesis gravidarum. She experienced motion sickness and complained about not looking young. ${ }^{41}$ After graduation, Erasmus (CD's brother) spent a life as a socialite and chronic invalid. ${ }^{74} \mathrm{He}$ as well suffered from abdominal pain and lethargy. CD's sister Caroline experienced "social and cognitive deterioration," and the oldest sister Marianne was described as "irritable" (Figure 1). Among CD's children, one died in infancy, one at juvenile age, and another one also at juvenile age. The surviving children suffered from frequent infections. CD's father was obese but there are no records of him having had illness. There is also no information regarding sickness of CD's father's sisters or brothers. The parents of CD's father seemed to have been unaffected as well. There are not enough data available for CD's father's side of the family to perform quantitative pedigree analysis.

\section{Discussion}

In reviewing the literature relevant to CD's illness, we have determined that MID is the most likely cause of his pleomorphic abnormalities. Despite a large number of possible differentials, his complaints were attributed to a MID because of the wide range of manifestations, the episodic nature of his complaints, the noteworthy family history, the phenotypic heterogeneity between affected family members, the triggering effect of stress or meals, and the beneficial effect of hydrotherapy and heat.
Arguments supporting CVS in CD are that he had developed periodic nausea and vomiting since his times as a student in Edinburgh and Cambridge, and the adult onset of CVS remained a severely compromising condition throughout his life. His CVS episodes increased in severity and duration with increasing age and bound him to bed for days or weeks, as in most CVS cases. A further argument for CVS in CD is the development of abnormal seasickness. Though not previously reported, the concurrence of CVS and seasickness suggests a pathogenetic link, and CVS was most likely the cause of abnormal seasickness. Abnormal seasickness bound CD to his hammock on the "Beagle" for days. The fact that he was quite fit during some land excursions on the expedition does not exclude CVS. A further argument for CVS in CD is his dental problem, a frequent finding in CVS patients, which is more likely due to damage from gastric acids rather than to his preference for sweets. The intermittent nature of CD's symptoms is also compatible with $\mathrm{CVS}^{47}{ }^{47} \mathrm{~A}$ further argument for CVS in CD is his beneficial reaction to hydrotherapy. "Water cure" was the only treatment that brought CD any relief, ${ }^{45,46}$ and likewise, CVS patients spend hours in a bath or under a shower. ${ }^{16}$ No other treatment before or afterward was effective. Hydrotherapy has not been previously reported to have a beneficial effect on CVS, but cannabinoid hyperemesis syndrome responded favorably to compulsive hot baths. ${ }^{75}$ Paradoxically, cannabis is predominantly known for its antiemetic properties. ${ }^{76}$ Only in cases of chronic abuse, hyperemesis may evolve, which is why chronic cannabis abuse should be included in the differential diagnoses of CVS. ${ }^{76-78}$ A further indication for a relation between cannabinoids and emesis is the fact that low levels of endocannabinoids are associated with motion sickness. ${ }^{79}$ Arguments against CVS in CD are that he did not recover completely after a CVS episode and that he improved only partially during warm weather conditions, as with most other CVS patients.

Several arguments for MID as the common cause of CD's complaints can be raised. The strongest argument is the wide range of organ involvement (brain, muscles, peripheral nerves, ears, heart, gut, skin). Multiorgan involvement included cerebral manifestations (episodes of weakness, episodes of memory loss, dyslexia, dizziness, presyncope, faintness, headache, panic attacks), muscular manifestations (exercise intolerance, overtiredness, exhaustion, prostration, easy fatigability, myalgia, muscle twitching), manifestations of peripheral nerves including autonomic fibers (polyneuropathy with hypoesthesia and dysesthesia in a glove-type distribution, increased sweating, temperature sensitivity, 
dysautonomia), vestibular manifestations, cardiac manifestations (palpitations, probably atrial fibrillation, chest pain), gastrointestinal manifestations (CVS, dental problems, abnormal seasickness, eructation, belching, flatulence), and dermatological manifestations (painful lips, dermatitis, eczema, occasional edema of the face) (Table 2). A second argument for MID in CD is the fact that episodes of CVS could be triggered by physical stress. ${ }^{47} \mathrm{~A}$ third argument is the family history indicating that at least one member (sister of CD's mother [Mary Anne]) suffered from a MID. Other family members presumably affected by a MID were the siblings Erasmus and Caroline, the mother and her siblings Sarah, Josiah, Richard, and Tom (Figure 1). The clinical manifestations of these family members were highly variable. Only a few of CD's symptoms do not fit with the diagnosis of a MID (Table 2).

Alternative explanations for CD's various symptoms are listed in Table 3. Transient weakness might not only be due to stroke-like episodes, seizures, or arrhythmias but may also be due to a cerebral vascular problem. Transient weakness could be due to carotid artery stenosis or intracranial artery stenosis. This arterial occlusive disease could be a manifestation of atherosclerosis, which itself may be a manifestation of a MID. ${ }^{80}$ It is also conceivable that transient weakness represents a transitory ischemic attack due to cardiac low output failure, but it is questionable if CD ever experienced heart failure, arterial hypotension, or autonomic disturbances leading to low output failure. An argument against a strokelike episode is that these usually last for weeks or months and are frequently associated with convulsive seizures. An argument against the presence of epilepsy is that convulsions, tongue bites, or secessus were never reported. Fatigue might be simply the consequence of the recurrent electrolyte disturbances and alkalosis from CVS. There are a number of FAODs associated with vomiting including very long chain acyl-CoA dehydrogenase deficiency, medium chain acyl-CoA dehydrogenase deficiency, multiple acyl-CoA dehydrogenase deficiency, short-chain acyl-CoA dehydrogenase deficiency, short-chain L-3-hydroxyacyl-CoA dehydrogenase deficiency, or carnitine palmitoyl transferase-1 deficiency. Arguments against FAODs, however, are that these disorders usually follow a more severe course (eg, sudden cardiac death), may be associated with rhabdomyolysis or myoglobinuria, do not follow a maternal trait of inheritance, and do not respond to hydrotherapy.

There are several reasons why it is unlikely that the differential diagnoses listed in Table 3 were the cause of CD's illness. First, it is obvious that CD suffered from a hereditary
Table 3 Differential diagnoses that have been proposed for Charles Darwin's illness

\begin{tabular}{|c|c|}
\hline Causes & Reference \\
\hline \multicolumn{2}{|l|}{ Psychiatric causes } \\
\hline Reaction to birth trauma & 51 \\
\hline Psychiatric disease & 50 \\
\hline Neurosis & 48 \\
\hline Hypomania & 49 \\
\hline Depression & 49 \\
\hline Hypochondria & 47,94 \\
\hline Bereavement syndrome & 47 \\
\hline Panic disorder & 95 \\
\hline Anxiety disorder, agoraphobia & 51,96 \\
\hline Neurasthenia & 97 \\
\hline Nervous indigestion & 98 \\
\hline Somatization disorder & 51 \\
\hline Obsessive compulsive disorder & 51 \\
\hline Repressed hatred towards father & 51 \\
\hline Device for father-son bonding & 51 \\
\hline Repressed hostility towards his wife & 51 \\
\hline Unexpressed grief for loss of mother & 51 \\
\hline Repressed anxiety over evolution & 51 \\
\hline Conflict with religious beliefs & 51 \\
\hline Repressed homosexual attraction to Fitzroy R & 51 \\
\hline Malingering (shamming) & 51 \\
\hline \multicolumn{2}{|l|}{ Central nervous system disease } \\
\hline Narcolepsy & 99 \\
\hline \multicolumn{2}{|l|}{ Ocular disease } \\
\hline Chronic eye strain & 100 \\
\hline \multicolumn{2}{|l|}{ Otologic } \\
\hline Meniere's disease & 51 \\
\hline \multicolumn{2}{|l|}{ Heart disease } \\
\hline Heart disease & 98 \\
\hline Atrial fibrillation & 101 \\
\hline \multicolumn{2}{|l|}{ Gastro-intestinal disorder } \\
\hline Irritable bowel syndrome & 101 \\
\hline Celiac disease & 47 \\
\hline \multicolumn{2}{|l|}{ Helicobacter infection } \\
\hline Crohn's disease & 101 \\
\hline Peptic ulcer & 101 \\
\hline Biliary tract disease, chronic cholecystitis & 48,101 \\
\hline Chronic appendicitis & 48 \\
\hline Duodenal ulcer & 48 \\
\hline Diaphragmatic hernia & 102 \\
\hline \multicolumn{2}{|l|}{ Metabolic disease } \\
\hline Mitochondrial disorder & 51 \\
\hline Intermittent porphyria & 103 \\
\hline Metabolic disease & 104 \\
\hline Gout & 70 \\
\hline Hyperinsulinism & 71 \\
\hline \multicolumn{2}{|l|}{ Infection } \\
\hline Chagas disease & 50 \\
\hline Amoeba infection & 48 \\
\hline Brucellosis & 105 \\
\hline Chilean fever & 48 \\
\hline Typhoid fever & 47 \\
\hline Smoldering hepatitis & 48 \\
\hline Borreliosis & 51 \\
\hline Malaria & 51 \\
\hline
\end{tabular}


Table 3 (Continued)

\begin{tabular}{ll}
\hline Causes & Source \\
\hline Pyorrhoea with septicemia & 48 \\
Helicobacter pylori infection & 52 \\
Candida overload & 52 \\
Intoxication & \\
Arsenic poisoning & 47 \\
Bismuth & 47 \\
Amyl nitrite & 47 \\
Quinine & 47 \\
Calomel (mercury) & 47 \\
Morphium & 47 \\
Exposure to preservative chemicals & 51 \\
Allergy & \\
Multiple allergies & 47 \\
Allergy & 106 \\
Pigeon allergy & 48 \\
Autoimmune & \\
Systemic lupus erythematosus & 51 \\
Blood & \\
Pyroluria & 51 \\
Others & \\
Lactose intolerance & 107 \\
\hline
\end{tabular}

disease, which is supported by the family history, showing not only affection of several family members but also similarities between the different individual phenotypes. Assuming that his disease was hereditary, infections, intoxications, autoimmune disease, or allergies could not have been causative. Second, none of the causes listed in Table 3 could sufficiently explain all manifestations occurring in $\mathrm{CD}$ and other affected family members. Though some of the clinical manifestations could be attributed to these differentials, MID remains the most suitable cause to explain the array of abnormalities by a common diagnosis. Transmission of CD's MID most likely follows an autosomal dominant trait of inheritance, why the mutated gene most likely locates in the nuclear DNA. Third, the transient, episodic nature of CD's complaints excludes many of the differentials listed in Table 3. The episodic nature of the complaints is typical for CVS and a number of other syndromic or nonsyndromic MIDs. Fourth, the only beneficial therapeutic effect on CD's symptoms could be achieved with hydrotherapy. Hardly any of the differentials listed in Table 3 respond markedly to hydrotherapy.

\section{Conclusion}

There are ample and stringent indications that $\mathrm{CD}$ suffered from an inherited, nonsyndromic, multisystem MID and that CVS in CD was attributable to the underlying MID. The definite diagnosis, however, remains speculative since no instrumental investigations were carried out that could prove or disprove a MID. FAODs are rather unlikely given their presentation, course, and reaction to treatment. Investigations of living offspring of $\mathrm{CD}$, including genetic studies, could further strengthen the suspicion that $\mathrm{CD}$ indeed suffered from a MID. Genetic investigations of CD's hairs are under way.

\section{Author contributions}

$\mathrm{JF}$ and JH analyzed and interpreted the historical patient data regarding CVS. JF analyzed available data with regard to their compatibility with a MID. JF and JH were major contributors in writing the manuscript. Both authors read and approved the final manuscript.

\section{Disclosure}

The authors report no conflicts of interest in this work.

\section{References}

1. Fleisher DR, Matar M. The cyclic vomiting syndrome: a report of 71 cases and literature review. J Pediatr Gastroenterol Nutr. 1993; 17(4):361-369.

2. Abell TL, Adams KA, Boles RG, et al. Cyclic vomiting syndrome in adults. Neurogastroenterol Motil. 2008;20(4):269-284.

3. Kumar N, Bashar Q, Reddy N, et al. Cyclic vomiting syndrome (CVS): is there a difference based on onset of symptoms - pediatric versus adult? BMC Gastroenterol. 2012;12:52.

4. Rinaldo P. Mitochondrial fatty acid oxidation disorders and cyclic vomiting syndrome. Dig Dis Sci. 1999;44(Suppl 8):97S-102S.

5. Keller K, Beule J, Scholz M, Pfnür M, Dippold W. [Cyclic vomiting syndrome (CVS) in adults - frequently overlooked?]. Z Gastroenterol. 2012;50(7):694-698. German.

6. Lee LY, Abbott L, Mahlangu B, Moodie SJ, Anderson S. The management of cyclic vomiting syndrome: a systematic review. Eur $J$ Gastroenterol Hepatol. 2012;24(9):1001-1006.

7. Hejazi RA, McCallum RW. Review article: cyclic vomiting syndrome in adults - rediscovering and redefining an old entity. Aliment Pharmacol Ther. 2011;34(3):263-273.

8. Galli JA, Sawaya RA, Friedenberg FK. Cannabinoid hyperemesis syndrome. Curr Drug Abuse Rev. 2011;4(4):241-249.

9. Pareek N, Fleisher DR, Abell T. Cyclic vomiting syndrome: what a gastroenterologist needs to know. Am J Gastroenterol. 2007;102(12): 2832-2840.

10. Prakash C, Staiano A, Rothbaum RJ, Clouse RE. Similarities in cyclic vomiting syndrome across age groups. Am J Gastroenterol. 2001;96(3):684-688.

11. Lin YP, Ni YH, Weng WC, Lee WT. Cyclic vomiting syndrome and migraine in children. $J$ Formos Med Assoc. 2011;110(6):382-387.

12. Boles RG. High degree of efficacy in the treatment of cyclic vomiting syndrome with combined co-enzyme Q10, L-carnitine and amitriptyline, a case series. BMC Neurol. 2011;11:102.

13. Hejazi RA, Lavenbarg TH, Pasnoor M, et al. Autonomic nerve function in adult patients with cyclic vomiting syndrome. Neurogastroenterol Motil. 2011;23(5):439-443.

14. Dong M, Li ZH, Li G. [Clinical characteristics of 41 children with cyclic vomiting syndrome]. Zhonghua Er Ke Za Zhi. 2008;46(6):450-453. Chinese.

15. Chelimsky G, Heller E, Buffington CA, Rackley R, Zhang D, Chelimsky T. Co-morbidities of interstitial cystitis. Front Neurosci. 2012;6:114. 
16. Abu-Arafeh I, Russell G. Cyclical vomiting syndrome in children: a population-based study. J Pediatr Gastroenterol Nutr. 1995;21(4): 454-458.

17. Cullen KJ, MacDonald WB. The periodic syndrome: its nature and prevalence. Med J Aust. 1963;50(2):167-173.

18. Fitzgerald M, Crushell E, Hickey C. Cyclic vomiting syndrome masking a fatal metabolic disease. Eur J Pediatr. 2013;172(5):707-710.

19. Boles RG, Lovett-Barr MR, Preston A, Li BU, Adams K. Treatment of cyclic vomiting syndrome with co-enzyme Q10 and amitriptyline, a retrospective study. BMC Neurol. 2010;10:10.

20. Camilleri M, Carlson P, Zinsmeister AR, et al. Mitochondrial DNA and gastrointestinal motor and sensory functions in health and functional gastrointestinal disorders. Am J Physiol Gastrointest Liver Physiol. 2009;296(3):G510-G516.

21. Zaki EA, Freilinger T, Klopstock T. Two common mitochondrial DNA polymorphisms are highly associated with migraine headache and cyclic vomiting syndrome. Cephalalgia. 2009;29(7):719-728.

22. Boles RG, Zaki EA, Lavenbarg T, et al. Are pediatric and adult-onset cyclic vomiting syndrome (CVS) biologically different conditions? Relationship of adult-onset CVS with the migraine and pediatric CVS-associated common mtDNA polymorphisms 16519T and 3010A. Neurogastroenterol Motil. 2009;21(9):936-e72.

23. Boles RG, Baldwin EE, Prezant TR. Combined cyclic vomiting and Kearns-Sayre syndromes. Pediatr Neurol. 2007;36(2):135-136.

24. Pavlakis SG, Phillips PC, DiMauro S, De Vivo DC, Rowland LP. Mitochondrial myopathy, encephalopathy, lactic acidosis, and strokelike episodes: a distinctive clinical syndrome. Ann Neurol. 1984; 16(4):481-488.

25. Nalini A, Gayathri N. Mitochondrial neurogastrointestinal encephalopathy in an Indian family with possible manifesting carriers of heterozygous TYMP mutation. J Neurol Sci. 2011;309(1-2): $131-135$.

26. Finsterer J, Ahting U. Mitochondrial depletion syndromes in children and adults. Can J Neurol Sci. 2013;40(5):635-644.

27. Finsterer J. Leigh and Leigh-like syndrome in children and adults. Pediatr Neurol. 2008;39(4):223-235.

28. Van Biervliet S, Verloo P, Vande Veldel S, et al. Abdominal pain and vomiting as first sign of mitochondrial disease. Acta Gastroenterol Belg. 2009;72(3):365-368.

29. Boles RG, Adams K, Li BU. Maternal inheritance in cyclic vomiting syndrome. Am J Med Genet A. 2005;133A(1):71-77.

30. Li BU, Lefevre F, Chelimsky GG, et al. North American Society for Pediatric Gastroenterology, Hepatology, and Nutrition consensus statement on the diagnosis and management of cyclic vomiting syndrome. J Pediatr Gastroenterol Nutr. 2008;47(3): 379-393.

31. Venkatesan T, Wagler S, Kumar N, et al. M2013 cyclic vomiting syndrome: quantitative pedigree analysis for maternal inheritance patterns in adults and children. Gastroenterology. 2010;138(5 Suppl 1): S-458.

32. Boles RG, Powers AL, Adams K. Cyclic vomiting syndrome plus. J Child Neurol. 2006;21(3):182-188.

33. Boles RG, Williams JC. Mitochondrial disease and cyclic vomiting syndrome. Dig Dis Sci. 1999;44(Suppl 8):103S-107S.

34. Van Driessche A, Sermijn E, Paemeleire K, Van Coster R, Vogelaers D. Cyclic vomiting syndrome: case report and short review of the literature. Acta Clin Belg. 2012;67(2):123-126.

35. Bullard J, Page NE. Cyclic vomiting syndrome: a disease in disguise. Pediatr Nurs. 2005;31(1):27-29.

36. Stickler GB. Relationship between cyclic vomiting syndrome and migraine. Clin Pediatr (Phila). 2005;44(6):505-508.

37. Boles RG, Adams K, Ito M, Li BU. Maternal inheritance in cyclic vomiting syndrome with neuromuscular disease. Am J Med Genet A. 2003;120A(4):474-482.

38. Erturk O, Uluduz D, Karaali-Savrun F. Efficacy of nebivolol and amitriptyline in the prophylaxis of cyclic vomiting syndrome: a case report. Neurologist. 2010;16(5):313-314.
39. Tack J, Talley NJ, Camilleri M, et al. Functional gastroduodenal disorders. Gastroenterology. 2006;130(5):1466-1479.

40. Stein MT, Katz RM, Jellinek MS, Cassidy L, Olness K. Cyclic vomiting. Pediatrics. 2001;107(Suppl 1):940-944.

41. Fleisher DR, Gornowicz B, Adams K, Burch R, Feldman EJ. Cyclic vomiting syndrome in 41 adults: the illness, the patients, and problems of management. BMC Med. 2005;3:20.

42. Forbes D, Fairbrother S. Cyclic nausea and vomiting in childhood. Aust Fam Physician. 2008;37(1-2):33-36.

43. Hikita T, Kodama H, Nakamoto N, et al. Effective prophylactic therapy for cyclic vomiting syndrome in children using valproate. Brain Dev. 2009;31(6):411-413.

44. Cyclic Vomiting Syndrome Association [homepage on the Internet]. Milwaukee, WI: Cyclic Vomiting Syndrome Association [updated October 10,2013]. Available from: http://www.cvsaonline.org/.Accessed August 12, 2013.

45. Hayman JA. Darwin's illness revisited. BMJ. 2009;339:b4968.

46. Hayman JA. Charles Darwin's impressions of New Zealand and Australia, and insights into his illness and his developing ideas on evolution. Med J Aust. 2009;191(11-12):660-663.

47. Campbell AK, Matthews SB. Darwin's illness revealed. Postgrad Med J. 2005;81(954):248-251.

48. Colp R Jr. Darwin's Illness. Gainsville, Florida: University Press of Florida; 2008:187-257 (appendix).

49. Lieb J. The paradoxical advantages and disadvantages of natural selection: the case history of Charles Darwin. Med Hypotheses. 2007;69(6):1375-1377.

50. Orrego F, Quintana C. Darwin's illness: a final diagnosis. Notes Rec $R$ Soc Lond. 2007;61(1):23-29.

51. Hayman J. Darwin's Illness. [doctoral thesis]. Melbourne: Melbourne University; 2012.

52. Darwin CR to Darwin SE (6 Sept 1831) Letter 119. [webpage on the Internet]. Cambridge: Darwin Correspondence Project [updated 2013]. Available from: http://www.darwinproject.ac.uk/entry-119/. Accessed Aug 2013.

53. Darwin CR to Fox WD (15 Oct 1829) Letter 73. [webpage on the Internet]. Cambridge: Darwin Correspondence Project [updated 2013]. Available from: http://www.darwinproject.ac.uk/entry-73/. Accessed Aug 2013.

54. Darwin CR to Wedgwood CS (May 1838) Letter 411. [webpage on the Internet]. Cambridge: Darwin Correspondence Project [updated 2013]. Available from: http://www.darwinproject.ac.uk/entry-411. Accessed Aug 2013

55. Darwin CR to Fox WD (7 June 1840) Letter 572. [webpage on the Internet]. Cambridge: Darwin Correspondence Project [updated 2013]. Available from: http://www.darwinproject.ac.uk/entry-572. Accessed Aug 2013.

56. Darwin CR to FitzRoy, Robert (20 Feb 1840) Letter 555 [webpage on the Internet]. Cambridge: Darwin Correspondence Project [updated 2013]. Available from: http://www.darwinproject.ac.uk/entry-555. Accessed Aug 2013.

57. Darwin CR to Darwin, Emma (12-24 Oct 1843) Letter 704 [webpage on the Internet]. Cambridge: Darwin Correspondence Project [updated 2013]. Available from: http://www.darwinproject.ac.uk/entry-704. Accessed Aug 2013.

58. Barlow N. The Autobiography of Charles Darwin 1809-1882. With original omissions restored. London: Collins; 1958.

59. Darwin CR to Hooker JD (14 July 1848) Letter 763 [webpage on the Internet]. Cambridge: Darwin Correspondence Project [updated 2013]. Available from: http://www.darwinproject.ac.uk/entry-763. Accessed Aug 2013.

60. Darwin CR to Hooker JD (31 Mar 1845) Letter 847 [webpage on the Internet]. Cambridge: Darwin Correspondence Project [updated 2013]. Available from: http://www.darwinproject.ac.uk/entry-847. Accessed Aug 2013.

61. DarwinCR toHookerJD(28Mar 1849)Letter 1236 [webpage on the Internet]. Cambridge: Darwin Correspondence Project [updated 2013]. Available from: http://www.darwinproject.ac.uk/entry-1236. Accessed Aug 2013. 
62. Darwin CR to Darwin SE (19 Mar 1849) Letter 1234 [webpage on the Internet]. Cambridge: Darwin Correspondence Project [updated 2013]. Available from: http://www.darwinproject.ac.uk/entry-1234. Accessed Aug 2013.

63. Darwin CR to Henslow JS (6 May 1849) Letter 1241 [webpage on the Internet]. Cambridge: Darwin Correspondence Project [updated 2013]. Available from: http:/www.darwinproject.ac.uk/entry-1241. Accessed Aug 2013.

64. Darwin CR to Fox WD (7 July 1849) Letter 1249 [webpage on the Internet]. Cambridge: Darwin Correspondence Project [updated 2013]. Available from: http://www.darwinproject.ac.uk/entry-1249. Accessed Aug 2013.

65. Browne J. Charles Darwin: The Power of Place. Princeton, NJ: Princeton University Press; 2002.

66. Darwin CR to Hooker JD (23 June 1862) Letter 3620 [webpage on the Internet]. Cambridge: Darwin Correspondence Project [updated 2013]. Available from: http:/www.darwinproject.ac.uk/entry-3620. Accessed Aug 2013.

67. Litchfield HE (1887). Recollections of Darwin's health. CUL-DAR112. A79-A82 [homepage on the Internet]. John van Wyhe, editor. Darwin Online. Available from: http://darwin-online.org.uk. Accessed Aug 2013.

68. Browne J. Darwin's Origin of Species. New York: Grove Press; 2006.

69. Darwin CR to Buckland FT (15 December 1864) Letter 4717F [webpage on the Internet]. Cambridge: Darwin Correspondence Project [updated 2013]. Available from: http://www.darwinproject.ac.uk/entry-4717f. Accessed Aug 2013.

70. Darwin CR to Chapman, John (16 May 1865) Letter 4834 [webpage on the Internet]. Cambridge: Darwin Correspondence Project [updated 2013]. Available from: http://www.darwinproject.ac.uk/entry-4834. Accessed Aug 2013.

71. Litchfield H. (nd) Recollections of Charles Darwin's death. CULDAR262.23.2 [homepage on the Internet]. John van Wyhe, editor Darwin Online. Available from: http://darwin-online.org.uk. Accessed Aug 2013.

72. Sauer GC. Charles Darwin consults a dermatologist. Int J Dermatol. 2000;39(6):474-478.

73. Wedgwood B, Wedgwood H. The Wedgwood Circle 1730-1897. London: Macmillan Publishing Co; 1980.

74. Healey E. Emma Darwin: The Inspirational Wife of a Genius. London: Headline Publisher; 2001.

75. Schmid SM, Lapaire O, Huang DJ, Jürgens FE, Güth U. Cannabinoid hyperemesis syndrome: an underreported entity causing nausea and vomiting of pregnancy. Arch Gynecol Obstet. 2011;284(5):1095-1097.

76. Chepyala P, Olden KW. Cyclic vomiting and compulsive bathing with chronic cannabis abuse. Clin Gastroenterol Hepatol. 2008;6(6): 710-712.

77. Donnino MW, Cocchi MN, Miller J, Fisher J. Cannabinoid hyperemesis: a case series. J Emerg Med. 2011;40(4):e63-e66.

78. Wallace EA, Andrews SE, Garmany CL, Jelley MJ. Cannabinoid hyperemesis syndrome: literature review and proposed diagnosis and treatment algorithm. South Med J. 2011;104(9):659-664.

79. Choukèr A, Kaufmann I, Kreth S, et al. Motion sickness, stress and the endocannabinoid system. PLoS One. 2010;5(5):e10752.

80. Finsterer J, Mahjoub SZ. Primary mitochondrial arteriopathy. Nutr Metab Cardiovasc Dis. 2012;22(5):393-399.

81. Desmond A, Moore J. Darwin. London: Penguin Books; 1991.

82. Darwin CR to Darwin WE (4 July 1862) Letter 3641 [webpage on the Internet]. Cambridge: Darwin Correspondence Project [updated 2013]. Available from: http:/www.darwinproject.ac.uk/entry-3641. Accessed Aug 2013.

83. Darwin CR to Henslow JS (20 Sept 1837) Letter 378 [webpage on the Internet]. Cambridge: Darwin Correspondence Project [updated 2013]. Available from: http://www.darwinproject.ac.uk/entry-378. Accessed Aug 2013.
84. Darwin CR to Henslow JS (14 Oct 1837) Letter 382 [webpage on the Internet]. Cambridge: Darwin Correspondence Project [updated 2013]. Available from: http://www.darwinproject.ac.uk/entry-382. Accessed Aug 2013.

85. Darwin C, Voyage of the Beagle. London: Henry Colburn; 1839.

86. Darwin CR to Darwin, Emma (1 July 1841) Letter 600 [webpage on the Internet]. Cambridge: Darwin Correspondence Project [updated 2013]. Available from: http://www.darwinproject.ac.uk/entry-600. Accessed Aug 2013.

87. Hooker JD. Reminiscences of Darwin. Nature. 1899;60:187-188.

88. Emma Darwin's diaries [webpage on the Internet]. John van Wyhe, editor. Darwin Online. Available from: http://darwin-online.org.uk/ EmmaDiaries.html. Accessed Aug 2013.

89. Darwin CR to Wedgwood, Emma (26 Jan 1839) Letter 493 [webpage on the Internet]. Cambridge: Darwin Correspondence Project [updated 2013]. Available from: http://www.darwinproject.ac.uk/entry-493. Accessed Aug 2013.

90. Emma Darwin, a century of family letters, 1792-1896. London: John Murray; 1915 [webpage on the Internet]. San Francisco, CA Biodiversity Heritage Library [updated August 18, 2009]. Available from: http://www.archive.org/details/emmadarwincentur02litc. Accessed Aug 2013.

91. Hutchinson R, Hunter D. Clinical Methods. 11th ed. London: Cassell and Co, Ltd; 1940.

92. Darwin CR to Covington, Syms (16 Jan 1859) Letter 2400 [webpage on the Internet]. Cambridge: Darwin Correspondence Project [updated 2013]. Available from: http://www.darwinproject.ac.uk/entry-2400. Accessed Aug 2013.

93. Darwin CR to Hooker JD (25 Jan 1864) Letter 4397 [webpage on the Internet]. Cambridge: Darwin Correspondence Project [updated 2013]. Available from: http://www.darwinproject.ac.uk/entry-4397. Accessed Aug 2013.

94. Hubble D. Charles Darwin and psychotherapy. Lancet. 1943;241(6231):129-133.

95. Barloon TJ, Noyes R Jr. Charles Darwin and panic disorder. JAMA. 1997;277(2):138-141.

96. Bernstein RE. What was Charles Darwin's illness? S Afr Med J. 1982;61(25):939.

97. Johnston WW. The ill health of Charles Darwin: its nature and its relation to his work. Amer Anthropologist. 1901;3(1):139-158.

98. Darwin CR. Autobiography 1809-1882. Barlow N, editor [1958], London, Collins; 2008.

99. Roberts HJ. Reflections on Darwin's illness. J Chronic Dis. 1966 19(7):723-725

100. Gould GM. Charles Darwin. Biographic Clinics. 1903;1:103.

101. Shanahan F. Darwinian dyspepsia: an extraordinary scientist, an ordinary illness, great dignity. Am J Gastroenterol. 2012;107(2): 161-164.

102. Kohn LA. Charles Darwin's chronic ill health. Bull Hist Med. 1963; 37:239-256.

103. King-Hele D, editor. The Essential Writings of Erasmus Darwin. London: MacGibbon and Kee; 1968:18-19.

104. Stetten D Jr. Gout. Perspect Biol Med. 1959;2:185.

105. Simpson GG. Charles Darwin in search of himself. Sci Am. 1958; 199:117-122.

106. Smith F. Charles Darwin's health problems: the allergy hypothesis. J Hist Biol. 1992;25(2):285-306.

107. Matthews SB, Waud JP, Roberts AG, Campbell AK. Systemic lactose intolerance: a new perspective on an old problem. Postgrad Med J. 2005;81(953):167-173.

108. Hayman J. Insights into CVS from Charles Darwin's Illness. Newsletter, Cyclical Vomiting Syndrome Association UK. 2013;43:18-23. 


\section{Publish your work in this journal}

The International Journal of General Medicine is an international, peer-reviewed open-access journal that focuses on general and internal medicine, pathogenesis, epidemiology, diagnosis, monitoring and treatment protocols. The journal is characterized by the rapid reporting of reviews, original research and clinical studies across all disease areas.

A key focus is the elucidation of disease processes and management protocols resulting in improved outcomes for the patient. The manuscript management system is completely online and includes a very quick and fair peer-review system. Visit http://www.dovepress.com/ testimonials.php to read real quotes from published authors.

Submit your manuscript here: http://www.dovepress.com/international-journal-of-general-medicine-journal 